\title{
Challenges in Design Studio Project Work Among Malaysian Architecture Students
}

\author{
Norzehan binti Ibrahim, Azman bin Hasan
}

\begin{abstract}
There is an issue of architecture students in Malaysia public universities burdened with design studio project. A study from a sample of 217 students shows 50 percent are at high levels of burden proving that these architecture students are very burdened with the projects given during the semester while the other 50 percent are at moderate level. Therefore, the study aims to identify the problems of architecture student in carrying out design studio project and identifying the needs of the study in addressing this problem. Researcher used qualitative research approaches based on literature reviews and interviews conducted. The information is based on previous studies related to the field of research conducted by the researcher. In the interview process, participants involved in the study were three architecture students from two public universities in Malaysia namely IIUM and UTM. Based on the literature review conducted, it is important for the public to know the real situation of architecture students in Malaysia toward improving their mental health and to give a clear picture to the institution about the effects and consequences that the students have to bear if this mental health problem are silenced from public and considered unimportant. The Self-Management Model which is to be produced is vital as a reference for the students, lecturers and institutions in dealing with silent killer which is mental health problems.
\end{abstract}

Keywords : Architecture student, burdened, design studio project, mental health problems, Self-Management Model

\section{INTRODUCTION}

$\mathrm{T}$ his Architectural education is usually assessed on the basis of project design compared to examination. This means that some deadlines throughout the semester often give a negative impact which leads to significant task burden (Hamer, 2016). This is evidenced by a study conducted by Ibrahim (2018) which shows that 50 percent of architecture student are at a high level that proves that architecture student is totally burden with the design studio projects given during the semester while the other 50 percent are at moderate level. The architecture students are increasingly burdensome when lecturers set a date for assigning different courses to architectural design studio project on the same day and time (Ibrahim, 2018). This proves a study done by Ahmad et al. (2014) which describe the architecture students' have a higher workloads compared to the other courses.

Ahmad et al. (2014) in his study stated that the

Revised Manuscript Received on December 05, 2019.

* Correspondence Author

Norzehan binti Ibrahim, Faculty of Technical and Vocational Education, Universiti Tun Hussein Onn Malaysia, 86400 Parit Raja, Johor. Email: zehanibrahim@gmail.com

Azman bin Hasan*, Faculty of Technical and Vocational Education, Universiti Tun Hussein Onn Malaysia, 86400 Parit Raja, Johor. Email: azmanh@uthm.edu.my
Architectural Design course shows the burden of studio classes is as heavy of a burden as the architecture normal teaching class. Hanafi (2016) support the statement stating that this course is a prerequisite to the design course for the next semester. Students are given a design studio project which needs to be completed within the specified timeframe. However, there are still students who felt burdened by the length of time given to complete the design studio project (Hanafi, 2016). This is evidenced by Keskeys (2017) in his article through a study conducted by the Indiana University that has revealed the architecture students had to spend more time doing design studio project and studying for a longer period of time each week compared to other courses.

As a result of these workloads, students have been depressed and this would impact on their mental health. Hill (2016) stated in the article that one respondent have been interviewed reported two of his coursemate had committed suicide as a result of the pressure they faced arising from the workloads. Waite and Braidwood (2016) through the results of Architect Journal's (AJ) annual student survey states that the pressure of architectural education are taking a dreadful toll on the mental health of the young architects. This statement is proven when one of the interviewed architecture student said that they had more tasks to be completed on top of attending classes for 20 plus hours a week compared to other majors (Graff, 2016). This resulted in sleep deprivation and stress which ultimately grew negative mindset towards college and university life (Graff, 2016).

\section{PROBLEM STATEMENT}

Architecture design education certainly gives too much work and students required to work hard to complete it. It is a broad and complex field where the workloads that the student needs to achieve is quite dense on top of the expected mastery of various skills and knowledge throughout the study courses (Hamer, 2016). The most complicated part is the design process which never felt completed during the period of the study (Hamer, 2016). Architectural education is normally assessed on design studio projects instead of examination, which means some deadlines throughout the semester often lead to significant task burden (Hamer, 2016). Deadlines for each coursework assignment cannot be changed arbitrarily and it is not possible for students to receive multiple deadlines within a week. It will cause students to stressed out and give a lot of pressure especially for new students who may lack in time management skills. As a result of these stress and anxiety, students are exposed to mental health problems and in extreme cases may lead to suicide (Hill, 2016).






\section{Challenges in Design Studio Project Work Among Malaysian Architecture Students}

The results of the study conducted by Ibrahim (2018) have shown that the architecture students at public universities in Malaysia are burdened with design studio project given by lecturers throughout the semester. Table 1.1 shows the analysis of the burden of workload level borne by the architectural students during the semester identified by looking at min score. It shows half of the students stated that the workload given during the semester was at the higher level while the other half were at moderate level. The results of this study proved that these architectural students were burdened in completing the design studio projects every semester.

Table 1.1: Analysis of each item for the workload constructs that are borne by the architecture students throughout the semester

\begin{tabular}{|c|c|c|c|c|c|c|}
\hline $\begin{array}{c}\text { Item } \\
\text { no. }\end{array}$ & $\begin{array}{l}\text { Item } \\
\text { code }\end{array}$ & $\begin{array}{l}\text { Total } \\
\text { score }\end{array}$ & Count & $\begin{array}{l}\text { Min } \\
\text { score }\end{array}$ & Level & $(\%)$ \\
\hline 94 & BT094 & 935 & 211 & 4.43 & High & \multirow{11}{*}{50} \\
\hline 93 & BT093 & 912 & 210 & 4.34 & High & \\
\hline 92 & BT092 & 898 & 210 & 4.28 & High & \\
\hline 88 & BT088 & 890 & 210 & 4.24 & High & \\
\hline 91 & BT091 & 887 & 210 & 4.22 & High & \\
\hline 87 & BT087 & 884 & 210 & 4.21 & High & \\
\hline 96 & BT096 & 877 & 210 & 4.18 & High & \\
\hline 95 & BT095 & 874 & 210 & 4.16 & High & \\
\hline 89 & BT089 & 870 & 210 & 4.14 & High & \\
\hline 90 & BT090 & 833 & 210 & 3.97 & High & \\
\hline 86 & BT086 & 815 & 212 & 3.84 & High & \\
\hline 107 & BT107 & 783 & 211 & 3.71 & Average & \multirow{11}{*}{50} \\
\hline 106 & BT106 & 768 & 211 & 3.64 & Average & \\
\hline 104 & BT104 & 757 & 210 & 3.60 & Average & \\
\hline 99 & BT099 & 755 & 211 & 3.58 & Average & \\
\hline 103 & BT103 & 728 & 210 & 3.47 & Average & \\
\hline 105 & BT105 & 710 & 210 & 3.38 & Average & \\
\hline 102 & BT102 & 664 & 210 & 3.16 & Average & \\
\hline 97 & BT097 & 585 & 211 & 2.77 & Average & \\
\hline 98 & BT098 & 553 & 210 & 2.63 & Average & \\
\hline 101 & BT101 & 526 & 210 & 2.50 & Average & \\
\hline 100 & BT100 & 514 & 210 & 2.45 & Average & \\
\hline
\end{tabular}

Problems faced by these architecture students while doing their design studio project that caused them to be burdens will definitely affect their mental health. Consequently, it may also cause them to experience low self-esteem, stress in life, social affair problems, immoral behavioural tendencies and use of violence to solve problems and thus increase the risk of mental illness (MOH, 2011). In this study, the researcher intends to identify the problem of architecture students in carrying out their design studio project and also to identifying the needs of the study in addressing this problem in preventing the mental health problems labelled as the "silence killer" by Psychologist, Dr. Adrian Lim. Therefore, a study to identify the situation and the phenomenon of architectural students whether in line with previous studies is required.

\section{RESEARCH PURPOSE}

The purpose of this study is to identify the problem of architecture student in carrying out design studio project given every semester. The study also aims to identify the needs of the study in addressing these problem. This study was conducted to be of benefit to academics, lecturers and students especially those who focus on architecture field as their primary careers. This study is vital to assess the real situation of architecture students in Malaysia.

\section{RESEARCH OBJECTIVES}

The study is for:

I. Identify the problem of architecture student in carrying out design studio project.

II. Identify research needs in addressing these problem.

\section{RESEARCH QUESTIONS}

The study focused on two questions concerning on:

I. What are the problems faced by architecture students in carrying out design studio project?

II. What are the needs of the study in addressing these problem?

\section{METHOD}

The study will be conducted using a qualitative research approaches based on previous literature review and interviews. Qualitative research approaches are very well suited to this research. It will be implemented because this approach covers a wide range of areas and is used to gain a deep understanding of the issues of interest and also suitable for exploring new or complex issues (Hennink, Hutter \& Bailey, 2012). The information is based on previous studies related to the field of research conducted by the researcher. In the interview process, participants involved in the study were three architecture students from public universities in Malaysia namely International Islamic University Malaysia, IIUM and University of Technology Malaysia, UTM.

\section{RESULT AND DISCUSSION}

Based on the first research question, the study conducted by Rawan and Kamaruddin (2009) shows that the problems associated with student attitudes are one of the problems when performing the design studio project. This is because students still have negative attitudes in learning. They are arrogant, lazy and scared to ask the lecturer if they have problems in learning and this can affect their emotions and academic performance (Rawan \& Kamaruddin, 2009). In addition, Tucker and Abbasi (2016) in their study show that students prefer to work individually because of their negative teamwork learning experiences. Among the factors accounting for the negative teamwork learning experiences are the unequal workload contribution, poor engagement in group meetings and also the poor quality of work contributed (Tucker \& Abbasi, 2016). Additionally, the dependence of a student when they first look at the work of another partner prior starting their design studio projects also influences the emotions and readiness of the student to carry out their tasks (Ibrahim, 2018).

The architecture students were also not exempted from facing social problems by engaging in social activities. They admit that they will always avoid friends when busy with design studio project that needed to be complete besides rarely exercise physically every day and only passively involved (Ibrahim, 2018).




Whelan (2014) in her article stated that in order to overcome the stress of heavy workloads, the respondents admitted to develop many bad practices where the majority of students would sleep late, skipping meal, not participating in social activities and co-curriculum and rarely exercising in order to complete design studio project right on time. This can be proven when Methanisa, (2016) in his article states that his friend's mood swing is due to insufficient sleep which had affected her relationship with her family and her boyfriend.

The living cost is also one of the problems that burdened the architecture student as Yasir (2016) stated in his article that architectural students are indeed burdened by their high cost of courses even though they had received a scholarship. Sadly, the initiative to increase pocket money to sustain life during a semester is not feasible due to time constraints in completing design studio project (Yasir, 2016). This problem is proved based on statements from former architecture director and dean of London's Cass School, Robert Mull. He said that "high fees, debts, the fear of debt, low wages, poor working practices and educational models that reflects aspects of practice on individualism and competition rather that collective action and mutual support have put intolerable pressure on those students who can still study ad has excluded many more" (Winston, 2016).

Ibrahim (2018) in the study showed that one of the problems that caused a burden was the time management problem. The findings show that students agree and acknowledge that the design studio project given each semester cause students to work for long hours in order to complete it. The burden of the tasks causes students to always think about it all the time even while at home with the family (Ibrahim, 2018). The time management problem also affects the activities of worship where most of them admitted to rarely read the scriptures according to their respective religions and hardly visit the place of worship every week during the period of the study (Ibrahim, 2018). This situation will negatively affect the students exposing them to be more vulnerable to bad and immoral social illnesses (Ahmad et al., 2014).

Based on the result from previous literature review, the researcher concluded that there are four main problems faced by architecture students in carrying out design studio project. The identified problems are time management, cost of living, social relationships and attitudes as shown in Figure 1.1 below:-

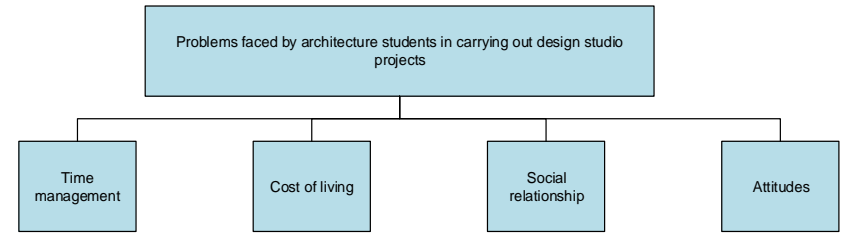

Figure 1.1: Four main problems faced by architecture students in carrying out design studio projects

Based on the four main issues discussed by the researcher, this can affect the mental health of architecture students due to the burden of tasks and assignments that are overloading them throughout the period of study. The Architect's Journal recently published the results of their student's surveys. The surveys were the first official survey done focused about the

mental well-being of British architecture students. The results are surprising whereby a quater of respondents reported they have been seeking treatment for mental health problems while another quarter of students reckoned they would need mental health treatment in the future (Kinnaird, 2016).

Based on the second research question, the theories that have been proved by earlier researchers have shown that this study needs to be done in addressing mental health problems caused by the burden borne by the architecture students in carrying out design studio project. To further support the issue of the design studio projects, Ibrahim (2018) conducted a preliminary survey by interviewing three architecture students from two public universities in Malaysia namely at the International Islamic University Malaysia, IIUM and University of Technology Malaysia, UTM. Among the feedbacks received are:

....studio workload? Hmmm ... for me it is very burdensome ... because it is very difficult for me to divide the time ... most of the time in the studio doing work... I have no time to play ... its is because there are too many requirements for a project especially the final project every semester ... the burden increased when there are overlapping tasks from other courses and deadlines that are close together to the final project submission date ...

(Architecture student 1) ... in my opinion, the architecture students workload is very heavy because there are other tasks that overlapped and the submission date is very close ... so these students must be feeling overwhelmed with things like that ... the time allocated for preparing and completing the design studio project is very limited ... and the students could not produce a good design ... In addition, sometimes when the project is almost ready to complete, suddenly the lecture came and ask to change the design ...how can we change the design in the last minute? We are very burdened with such requests..

(Architecture student 2)

...not enough sleep is due to time management student. If the students manage it properly, their sleep will be enough. Of course it affects our health ... because when you don't feel like sleep, you have to stay up longer...if you don't do your work, it can't be finish, then that's going to be a problem... hence, you got to get some coffee or what ever it takes to stay awake to get the stuff done ... when tomorrow comes, sometimes I need wake up early in the morning just to go to class...haha! Sometimes my head hurts, sometimes not...but still its always hard to focus in the class...because of lack of sleep, you will just go to class just for the sake of going and get nothing out of the class...so the conclusion is of course it will affect the health and weakened your immune system terribly...

(Architecture student 3)

The preliminary results conducted by Ibrahim (2018) have shown that the architecture students are burdened with design studio projects that need to be completed to prevent them from discontinuing their studies for the next semester. They admitted that due to the project's work requirements they were deprived of sleep and had to consume coffee just to stay awake. Hence, the problems faced by architecture






\section{Challenges in Design Studio Project Work Among Malaysian Architecture Students}

students in Malaysia that had caused them to be overwhelmed would indeed have adverse effects on their mental health. As a result, they may experience feelings of low self-esteem, stress in life, social relationships problem, immoral behavior and use of violence to solve problems and thus increase the risk of mental illness (MOH, 2011).

The findings from the initial survey showed that these architecture students are burdensome and need solutions to minimize these problems from becoming more serious. According to the interviewees, the burden borne entirely indicates that it is desirable to develop a Self-Management Model to architecture students. To alleviate this problem, Alias (2007) and Percy (2010) stated the importance of self-management for students involving one's level of action to manage time, anxiety, stress, risk to situations requiring adaptation and adaptation skills for self-stability and environment. Therefore, Self-Management Model is needed for students, lecturers and institutions in dealing with the silent killer which is mental health problems (Lim, 2017).

\section{CONCLUSION}

In conclusion, it is clear that there are problems faced by architecture students in carrying out their design studio projects given by lecturers in every semester. With the evidence shown by previous researchers, architecture is indeed a course that is not easy to master and there are problems that make these architecture students overwhelmed by burdened which can affect their mental health. With this study, it will give a clear picture to the institution about the effects and consequences that the students suffered if this mental health problem is not publicly known and taken lightly. The Self-Management Model is needed to refer to students, lecturers and institutions in dealing with this silent killer which is mental health problems. With this Self-Management Model, they are able to learn and practice healthy life practices to ensure their learning runs smoothly without any difficulties impacting their mental health. This problem will cause difficulties in producing highly skilled graduates and highly skilled individuals to improve the country's economic growth.

\section{REFERENCES}

1. Ahmad, A. S. H., Rahman, A. M. A., Nawawi, N. M., Ibrahim, N., Razali, M. M. F. M., Surat, M., \& Yaacob, N. M., (2014). Halatuju Pendidikan Senibina di Malaysia. Terbitan Universiti Putra Malaysia, UPM, Serdang. Retrieved on 22 December 2018, from http://www.moe.gov.my/images/Terbitan/Rujukan-akademik/ Hala \%20Tuju\%20 Pendidikan\%20Seni\%20Bina\%20di\%20 Malaysia.pdf

2. Alias, I. (2007). "Pengurusan Kendiri: Teras Perilaku Bestari Ke Arah Kegemilangan Organisasi”. Jabatan Perkhidmatan Awam. Bahagian Perkhidmatan. Retrieved on 12 November 2018, from http://docs.jpa.gov.my/docs/pelbagai/ubulanan /2007/BK-sept.pdf

3. Awaluddin, A. (2013). MyHEALTH. Kementerian Kesihatan Malaysia. Hubungkait antara Kesejahteraan Kesihatan Fizikal dan Mental. Retrieved on 22 October 2018, from http://www.myhealth.gov.my/hubungkait-antara-kesejahteraan-kesiha tan-fizikal-dan-mental/

4. Graff, C. (2014). Kentwired. Architecture Students Suffer From Sleep Deprivation, Study Says. Retrieved on 15 October 2018, from http://www.kentwired.com /latest_ updates/ article_23fc889e-790e-11e4-83c2-13c76fe91d21.html

5. Hamer, S. (2016). Portico. Mental Health \& Wellbeing for Architecture Students. Retrieved on 15 October 2018, from http://portico.space/journal//mental-health-wellbeing-while-studyingarchitecture
6. Hanafi, M. N. (2016). Pembangunan dan Penentusahan Rubrik Pentaksiran Prestasi Bagi Mentaksir Projek Reka Bentuk Seni Bina di Politeknik Malaysia. Universiti Pendidikan Sultan Idris

7. Hennink, M., Hutter, I. \& Bailey, A. (2012). Qualitative research methods. SAGE Publication.

8. Hill, A. (2016). Survey: $25 \%$ of UK architecture students treated for mental health problems. Retrieved on 15 October 2018, from https://www.theguardian.com

/education/2016/jul/28/uk-architecture-students-mental-health-proble marchitects-journal-survey

9. Ibrahim, N. (2018). Faktor-Faktor Yang Mempengaruhi Kesihatan Fizikal Ke Arah Pencapaian Akademik Pelajar Jurusan Senibina Di UIAM Dan UTM. Fakulti Pendidikan Teknikal dan Vokasional Universiti Tun Hussein Onn Malaysia.

10. Ministry of Health (2011). Kesihatan Mental. Health Education Division, Ministry of Health Malaysia.

11. Keskeys, P. (2017). Architizer. Architecture Students, All-Nighters and the "Fetishization of Exhaustion". Retrieved on 15 October 2018, from

https://architizer.com/blog/dear-architect-students-you-have-a-proble $\mathrm{m} /$

12. Kinnaird, B. (2016). Archi Parlour. An anxious discipline. Retrieved on 15 October 2018, from http://archiparlour.org/an-anxious-discipline/

13. Lim, A. (2017). Faktor ekonomi, tekanan keluarga punca belia sakit mental. Retrieved on 22 October 2018, from https://www.freemalaysiatoday.com/category

/bahasa/2017/06/30/faktor-ekonomi-tekanan-keluarga-punca-belia-sa kit-mental/

14. Methanisa, K. (2016). VICE. I'm going to University to Learn Architecture and It's Making Me So Depressed. Retrieved on 15 October 2018, from https://www.vice.com/en_id/article/mgj5ax/im-going-to-university-to -learn-architecture-and-its-making-me-so-depressed

15. Percy, E. (2010). Kompentensi personal (pengurusan kendiri). Retrieved on 28 December 2018, from https://www.slideshare.net/cethrington/kompentensi-personal-pengur usan-kendiri

16. Rawan, N. M \& Kamaruddin, M. I. (2009). Kaitan Faktor Penyumbang Dengan Kecemerlangan Akademik Pelajar Asrama Harian. Fakult Pendidikan Universiti Teknologi Malaysia.

17. Tucker, R. \& Abbasi, N. (2016). Bad attitudes: Journal of Learning Design. Why design students dislike teamwork. Deakin University. Vol. 9 No. 1

18. Waite, R. \& Braidwood, E. (2016). Architects' Journal. Mental health problems exposed by AJ student survey 2016. Retrieved on 15 October 2018 ,

from https://www.architectsjournal.co.uk/news/mental-health-problems-ex posed-byaj-student-survey-2016/10009173.article

19. Whelan, J. (2014). Arch Daily. Mental Health in Architecture School Can the Culture Change? Retrieved on 15 October 2018, from https://www.archdaily.com/498397/mental-health-in-architecture-sch ool-can-the-culture-change

20. Winston, A. (2016). Dezeen. Quarter of UK architecture students report mental health issues. Retrieved on 26 October 2018, from https://www.dezeen.com

/2016/07/29/quarter-uk-architecture-students-mental-health-issues-st udent-survey-education-architects-journal/

21. Yasir, M. A. (2016) Mengapa Jurusan Senibina Bukan Untuk Anda Pensyarah Senibina di Universiti Teknologi Malaysia. Retrieved on 22 December 2018, from https://www.infopelajar2u.com/10-sebab-mengapa-jurusan-senibina mungkin-bukan-untuk-anda/

\section{AUTHORS PROFILE}



Norzehan binti Ibrahim received her Bachelor of Science (Architectural Studies) (Hons) from International Islamic University Malaysia (IIUM) in 2013. After graduating from her bachelor degree, she joined Arkitek SA Noh, KL as junior architect for 3 years. She got her Master of Technical and Vocational Education from Universiti Tun Hussein Onn Malaysia (UTHM) in 2018. She is currently a PhD student in UTHM. Her research interest is in architecture students' self-management. She has published 1 paper in Internationa Conference on Technology and

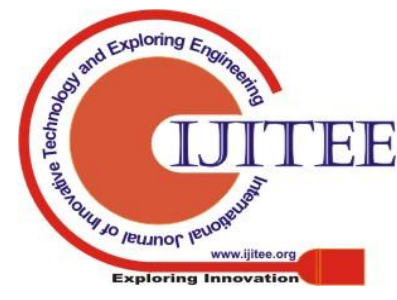




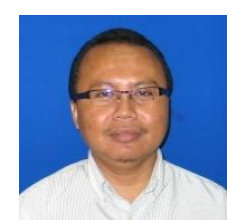

Prof. Madya Ts. Dr. Azman bin Hasan received his Bachelor of Civil Engineering (Hons) from Institu Teknologi Tun Hussein Onn (ITTHO) in 2000 and Master of Technical Education from Kolej Universiti Teknologi Tun Hussein Onn (KUiTTHO) in 2001. He was awarded $\mathrm{PhD}$ from Universiti Teknologi Malaysia (UTM) in 2012. He is currently a Deputy Dean (Student Affairs and Alumni) and Associate Professor from Faculty of Technical and Vocational Education (FPTV) Universiti Tun Hussein Onn Malaysia (UTHM). He is a member of Malaysia Board of Technologists (MBOT). He has over 17 years of teaching experience and 8 years of research experience. His research interest is in Technical and Vocational Education, Assessment and Evaluation in Education, Engineering Education, Instructional Design and Classroom Teaching and Learning. 